\title{
SYNERGISM BETWEEN LH AND FSH IN THE INDUCTION OF OVULATION
}

\author{
A. P. LABHSETWAR \\ Pharmaceuticals Division, ICI, Alderley Park, Macclesfield, Cheshire
}

(Received 16th Fuly 1970)

\begin{abstract}
Summary. A possible synergistic participation of $\mathrm{LH}$ and FSH in the ovulatory process was explored by intravenous administration of subthreshold doses of LH and/or FSH to rats with 4-day oestrous cycles, in which ovulation was blocked by a potent anti-oestrogen-ICI 46,474. The individual gonadotrophins in the doses used were only marginally active in restoring ovulation but, when given in combination, they potentiated the incidence of ovulation in four different experiments. It is postulated that both LH and FSH synergize with each other in the induction of ovulation as they do in causing growth of follicle.
\end{abstract}

It is generally accepted that luteinizing hormone (LH) is involved in ovulation (Harris \& Campbell, 1966). In recent years it has become apparent that ovulation in rats (Galigaris, Astrada \& Teleisnik, 1967; Goldman \& Mahesh, 1968; McClintock \& Schwartz, 1968), humans (see Jaffe \& Midgley, 1969, who give further references), hamsters (Keever \& Greenwald, 1967) and sheep (Santolucito, Clegg \& Cole, 1960; Robertson \& Hutchinson, 1962) is associated with depletion of pituitary follicle stimulating hormone (FSH) stores and/or elevated plasma FSH levels. Temporally, LH and FSH appear to be secreted simultaneously rather than sequentially (McClintock \& Schwartz, 1968; Jaffe \& Midgley, 1969). This has raised the question about the possible participation of FSH in the ovulatory process (Goldman \& Mahesh, 1969; Harrington \& Elton, 1969). In an earlier study, it was found that $10 \mu \mathrm{g}$ FsH injected into the androgen-induced, persistent oestrous rats produced ovulation in $40 \%$ of rats (Labhsetwar, 1970c). In a subsequent study, we found that the serum from the sterilized rats contained significantly more LH than that from the cyclic rats killed on the day of oestrus (Labhsetwar, 1970d). It was, therefore, thought that exogenous FSH may have synergized with endogenous LH in evoking ovulation. A synergism between LH and FSH has long been known to exist during the growth period of the follicle (Hisaw, 1947). It was, therefore, suspected that the same synergism may extend to include the ovulatory process itself. This hypothesis was tested in rats by using subthreshold doses of $\mathrm{LH}$ in conjunction with 'small' doses of FSH which by themselves were only minimally active. The approach was similar to that used earlier to determine a threshold dose of LH for ovulation (Labhsetwar, 1970a). Ovulation was blocked by a single oral dose of a potent anti-oestrogen-ICI 46,474 (trans-1-( $p$ - $\beta$-dimethyl- 
aminoethoxyphenyl)-1,2-diphenylbut-1-ene)-and then attempts were made to restore it by gonadotrophins given either singly or in combination. Evidence presented elsewhere shows that the compound blocks ovulation by interfering with the positive feedback of oestrogen, since its effect can be overcome either by oestrogen or by LH releasing factor (Labhsetwar, 1970b). Furthermore, $5 \mu \mathrm{g}$ of the compound which was systemically inactive, when implanted stereotaxically into the hypothalamus or hypophysis, interfered with ovulation but vehicle (cocoa butter) alone did not (Bainbridge \& Labhsetwar, unpublished observations), attesting the central action of the anti-oestrogen.

The rats used were Wistar derived and exposed to a 14-hr light: 10-hr dark cycle. They had at least one 4-day oestrous cycle before being used in the experiment. At 17.00 hours on the day of di-oestrus, i.e. the day before prooestrus, all rats received orally $0.5 \mathrm{mg} / \mathrm{kg}$ of the anti-oestrogen (ICI 46,474) as described before (Labhsetwar, 1970a). On the following day, i.e. the day of pro-oestrus, rats were usually divided into three or four groups (four to five

TABLE 1

INDUCTION OF OVULATION WITH LH AND/OR FSH IN RATS PRETREATED WITH ANTI-OESTROGEN ICI 46,474

\begin{tabular}{|c|c|c|c|c|}
\hline \multirow[b]{2}{*}{ Exp. no. } & \multicolumn{4}{|c|}{ Group } \\
\hline & $\begin{array}{c}A \\
(2 \mu g L H)\end{array}$ & $\begin{array}{c}B \\
(5 \mu g F S H)\end{array}$ & $\begin{array}{c}C \\
(L H+F S H)\end{array}$ & $\begin{array}{c}D \\
(0.5 \mathrm{ml} \text { saline })\end{array}$ \\
\hline $\begin{array}{l}1 \\
2 \\
3 \\
4\end{array}$ & $\begin{array}{l}0 / 4 \dagger \\
1 / 5 \\
2 / 5 \\
0 / 4 \ddagger\end{array}$ & $\begin{array}{l}0 / 5 \\
0 / 5 \\
1 / 5 \\
1 / 4\end{array}$ & $\begin{array}{l}3 / 4 \\
2 / 5 \\
4 / 5 \\
4 / 4 \ddagger\end{array}$ & $\begin{array}{l}0 / 4 \\
0 / 4 \$ \\
0 / 3 \$ \\
-\end{array}$ \\
\hline Total & $3 / 18(17 \%)$ & $2 / 19(10 \%)$ & $13 / 18(72 \%)^{*}$ & $0 / 11(0 \%)$ \\
\hline $\begin{array}{l}\text { Ova/ovulating rat } \\
\text { (Mean } \pm \text { S.E.) }\end{array}$ & $7 \cdot 7 \pm 2 \cdot 6$ & 12.5 & $7 \cdot 1 \pm 1 \cdot 3^{* *}$ & 0 \\
\hline
\end{tabular}

* $P<0.01$ by Chi-square test when compared with the sum of Groups A and B.

** Significantly different $(P<0.05)$ from ova count in untreated control rats killed on the morning of oestrus: $11 \pm 0 \cdot 6(n=9)$.

$\dagger$ Each value represents rats ovulating/number treated.

$\$ 1 \mu \mathrm{g} \mathrm{LH}$.

$\S 1 \mathrm{ml}$ saline.

rats/group) each group receiving, LH, FSH, LH and FSH, or saline. All gonadotrophin injections $(0.5 \mathrm{ml}$ saline) were made through the tail vein between 14.00 and 14.30 hours in conscious animals to eliminate the possible effects of anaesthesia. When given together, $\mathbf{L H}$ was given first and FSH 3 to 5 min later, using separate syringes. On the morning of expected oestrus, all rats were killed with ether and tubal ova/rat counted as described before (Labhsetwar, 1970a). The experiment was replicated three times at widely different intervals.

As little as $0.5 \mathrm{mg} / \mathrm{kg}$ of the anti-oestrogen completely blocked ovulation in thirty out of thirty-one rats, as indicated previously (Labhsetwar, 1970a), which indicates that there is virtually no chance of 'escape' ovulation at this dose level. Injection of 0.5 or $1 \mathrm{ml}$ of saline alone on the day of pro-oestrus failed to restore ovulation in any of the rats (Group D, Table 1). Similarly, a dose of 1 or $2 \mu \mathrm{g}$ of $\mathrm{LH}$ (NIH-S-14) (Group A), which was less than half the threshold 
dose of $5 \mu \mathrm{g}$ estimated earlier (Labhsetwar, 1970a), and $5 \mu \mathrm{g}$ FSH (NIH-s-6) (Group B) were only marginally active in restoring ovulation in four different experiments. By contrast, when the two gonadotrophins were given in combination (Group $G$ ), the incidence of ovulation was higher than the sum of the two groups receiving gonadotrophins individually $(P<0 \cdot 01)$. The ovulation rate (ova/ovulating rat), in Group C, was below that found in the untreated control. It is unlikely that this synergism stems from contamination of FSH with LH, since such a contamination would not be expected to exceed $0.02 \mu \mathrm{g}$ in a dose of $5 \mu \mathrm{g}$ of FSH according to the supplier of the hormone. It is also not possible to attribute the synergism to double the volume of the vehicle $(0.5 \mathrm{ml}$ for each gonadotrophin) injected in Group $\mathrm{G}$ since injection of $1 \mathrm{ml}$ saline totally failed to restore ovulation (Group D, Exps. 2 and 3). The data thus provide. evidence for potentiation between $\mathbf{L H}$ and FSH in the induction of ovulation. The fact that this synergism did not result in ovulation in $100 \%$ of the rats (Group $\mathrm{C}$ ) with a normal yield of ova indicates that different combinations of individual gonadotrophins might improve both the incidence of ovulation and ovulation rate. It is postulated that both $\mathrm{LH}$ and FSH synergistically participate in the ovulatory process as they do in causing the follicular growth.

The author thanks Miss Rosemary Chester for providing technical assistance and the Endocrine Study Section, NIH, Bethesda, Md., U.S.A., for generous gifts of gonadotrophins.

\section{REFERENCES}

Galigaris, L., Astrada, J. J. \& Teleisnik, S. (1967) Pituitary fsh concentrations in the rat during the estrous cycle. Endocrinology, 81, 1261.

GOLDMAN, B. D. \& MAHESH, V. B. (1968) Fluctuations in pituitary FSH during the ovulatory cycle in the rat and a possible role of FSH in the induction of ovulation. Endocrinology, 83, 97.

Goldman, B. D. \& MAHESH V. B. (1969) A possible role of acute Fsh-release in ovulation in the hamster as demonstrated by utilization of antibodies to LH and PSH. Endocrinology, 84, 236.

Harrington, F. E. \& Elton, R. L. (1969) Induction of ovulation in adult rats with follicle stimulating hormone. Proc. Soc. exp. Biol. Med. 132, 841.

HARRIs, G. W. \& CAMPBELL, H. J. (1966) The regulation of the secretion of luteinizing hormone and ovulation. In: The Pituitary Gland, Vol. 2, p. 99. Eds. G. W. Harris and B. T. Donovan. University of Galifornia Press, Berkeley.

Hisaw, F. L. (1947) Development of the Graafian follicle and ovulation. Physiol. Rev. 27, 95.

JAFFE, R. B. \& MIDGLEY, A. R., JR (1969) Current status of human gonadotropin radioimmunoassay. Obstet, gynec. Surv. 24, 200.

KeEver, J. E. \& GREENWALD, G. S. (1967) Effect of oestrogen and progesterone on pituitary gonadotrophin content of the cyclic hamster. Acta endocr., Copenh. 56, 244.

LABHSETwAR, A. P. (1970a) Estimation of the minimum amount of luteinizing hormone secreted for ovulation in rats. . Endocr. 46, 551.

LABHSETWAR, A. P. (1970b) Role of oestrogen in spontaneous ovulation demonstrated by the use of an antagonist of oestrogen, I.C.I. 46,474. Nature, Lond. 225, 80.

LABHSETWAR, A. P. (1970c) Ovarian sensitivity to ovulatory stimuli in the androgen-induced persistent-oestrous rats. Acta endocr., Copenh. (In press).

LABHSETWAR, A. P. (1970d) The serum level of immunoreactive LH in intact and spayed androgensterilized rats. F. Reprod. Fert. 23, 349.

McCuintock, J. \& Schwartz, N. (1968) Changes in pituitary and plasma follicle stimulating hormone concentrations during the rat estrous cycle. Endocrinology, 83, 433.

Robertson, H. A. \& Hutchinson, A. S. M. (1962) The levels of FSH and LH in the pituitary of the ewe in relation to follicular growth and ovulation. F. Endocr. 24, 143.

Santoluctro, J. A., CleggG, M. T. \& Cole, H. H. (1960) Pituitary gonadotrophins in the ewe at different stages of the estrous cycle. Endocrinology, 66, 273. 